\title{
Event-specific detection of transgenic potato AV43-6-G7 using real-time and digital PCR methods
}

\author{
Hongwei Gao ${ }^{1 *}$, Xiaofan Yu ${ }^{2}$, Tingting Deng ${ }^{3}$, Min Sun ${ }^{1}$, Xizhi Xiao ${ }^{1}$, Xin Huang ${ }^{3}$, Ying Chen $^{3}$ and Ronggui $\mathrm{Li}^{2}$
}

\begin{abstract}
Background: The isolation of unknown DNA sequences flanked by known sequences is an important task in the event-specific detection of GMOs. None of event-specific detection method was developed based on the junction sequence of an exogenous integrant in the transgenic potato AV43-6-G7.

Results: The flanking sequence between the exogenous fragment and recombinant chromosome of this potato was successfully acquired through exogenous gene 5'-RACE. The event-specific primers and Taqman probe were designed to amplify fragments spanning the exogenous DNA and potato genomic DNA. The specific real-time PCR and digital PCR detection methods for AV43-6-G7 potato were established based on primers designed according to the flanking sequences. The detection limit of the qualitative PCR assay was $0.01 \%$ for AV43-6-G7 potato in $100 \mathrm{ng}$ of potato genomic DNA, corresponding to approximately 11.6 copies of the potato haploid genome. The ddPCR assays for Potato AV43-6-G7 achieved a limit of quantification of approximately 58 target copies, with RSD $\leq 25 \%$. The aLOQ of this system was approximately 1.2 copies.
\end{abstract}

Conclusions: These results indicated that these event-specific methods would be useful for the identification of potato AV43-6-G7.

Keywords: Transgenic, Potato AV43-6-G7, Flanking sequence, Event Specific, Real-time PCR, Detection

\section{Background}

Since the first genetically modified tomato was approved, the number and production of genetically modified (GM) crops have continuously increased [1]. According to the International Service for the Acquisition of AgriBiotech Applications (ISAAA), 29 types of plants and 390 transgenic events were developed and commercialized worldwide by the end of March 2016 [2]. However, the perceived risks of genetically modified organisms (GMOs) to food safety and the environment have raised concerns [3]. To provide consumers with information on food, many countries have developed legislations to determine the threshold of GMO ingredients. The threshold for mixing GMOs in feed and foodstuffs are 0.9 \% in EU, 3 \% in Korea, 5 \% in Japan, and 1 \% in New Zealand and Australia [4]. In China, the mandatory

\footnotetext{
* Correspondence: ghw75@126.com

${ }^{1}$ Shandong Entry-Exit Inspection and Quarantine Bureau of People's Republic of China, Qingdao, China

Full list of author information is available at the end of the article
}

labelling of GMO products is required without setting a clear threshold value according to the Regulations on Administration of Agricultural GMOs Safety [5].

The isolation of unknown DNA sequences flanked by known sequences is an important task in the eventspecific detection of GMOs. Both rapid amplification of cDNA ends (RACE) and thermal asymmetric interlaced PCR (TAIL-PCR) are effective methods for this purpose $[6,7]$. Fraiturea et al. [8] also used a DNA walking strategy using a genome walking kit on rice products. To comply with GMO labelling regulations and ensure product legality and traceability, event-specific detection methods are essential for GMO identification and quantification. Event-specific detection was primarily performed at the DNA level using polymerase chain reaction (PCR)-based methods because of its high specificity for the flanking sequence of the exogenous integrant. In case of quantitative analysis, the Taqman-based real-time quantitative PCR (qPCR) method is preferred, reflecting the high accuracy (how close a measured value 
is to the actual value) and precision (how close the measured values are to each other) of this method. However, this method has some obvious drawbacks. Notably, PCR inhibitors, such as chloroform, ionic detergents, etc., the experience of the technicians, and the matrix effect of the PCR tubes affect standard curve-based qPCR [9]. Particularly, the significant bias observed when the target is present at low concentrations could seriously limit the use of qPCR [9] Another requirement for qPCR is reference material for GMO at serial concentrations, as standard curves for quantities of endogene and exogene are prepared separately. The lack of certified reference material has been also a hindrance for qPCR. Despite the shortcomings of $\mathrm{qPCR}$, this method is convenient for qualitative detection and cheap in terms of instruments and reagents compared with $\mathrm{dPCR}$.

Digital PCR (dPCR) has rapidly developed since it was first conceived in the 1992 [10]. In dPCR, the reaction mixture is distributed in a large number of partitions containing zero, one or more copies of the target nucleic acid. After end-point amplification, the signal would be positive (1) or negative (0) for partitioned samples [10]. The absolute number of target nucleic acid molecules in the original sample prior to partitioning can be calculated from the ratio of positive to total partitions using Poisson distribution . Compared with the real-time PCR methods, PCR inhibitors do not impact $\mathrm{dPCR}$, and this method does not need reference material for GMO at serial concentrations [11]. Digital PCR also is an effective approach to detect SNP variants in a diluted target sample $[12,13]$. The development and application of absolute quantitative detection through the duplex chamber-based digital PCR of genetically modified maize events has been reported [13]. Stevanato demonstrated that $\mathrm{dPCR}$ could differentiate all varieties of sugar beet samples carrying specific SNP alleles associated with flowering at low concentrations ( $1 \%)$ of the target sequence, while qPCR and HRM showed only a moderate frequency (10 \%) [12].

Thus, this technique is better suited for internationaltrade applications. Currently, two designated dPCR technologies are commercially available: micro fluidic chamber digital PCR (cdPCR) and emulsion droplet digital PCR (ddPCR). Both commercial systems enable suitable GMO testing. According to our experience, each sample would cost approximately US $\$ 12.1$ in ddPCR, while each sample should cost US $\$ 150$ to US $\$ 400$ per chip or plate in cdPCR [14]. In addition, ddPCR has higher repeatability than cdPCR according to the results of preliminary experiments using three genes [data not shown].

Potato is one of the first important transgenic plants [15]. The main purposes of gene transfer technology for potato were to improve the quality of potatoes and enhance pest-resistant varieties. Monsanto, a company in US, developed a range of anti-coleopteran pests and transgenic potatoes against leafroll virus prior to 1997 [16]. Recently, the quality of potato starch has been improved in more commercial transgenic potatoes, such as transgenic potato Amflora (EH92-527-1 potato) and transgenic potato AM04-1020 [17, 18]. These transgenic potatoes produce amylose-free starch through the antisense inhibition of the gene encoding granule bound starch synthase I (GBSSI) [19]. These improved functionalities are not only promising for technical applications in paper and textile, but also in the food industry for the production of dairy products, soups, sauces and noodles. The transgenic potato AV43-6-G7 in the present study is a variety of starch potato intended for starch isolation by the starch industry, and the starch might undergo further processing.

In the present study, the exogenous gene fragment and flanking sequence of transgenic potato AV43-6-G7 were obtained using the $5^{\prime}$-RACE method. According to information about the determined sequence, a pair of primers and a Taqman probe were designed based on the exogenous fragment and endogenous chromosomal sequence of potatoes. An event-specific detection method was developed for the transgenic potato AV43-6-G7 using real-time PCR and ddPCR.

\section{Methods}

Text materials and DNA preparation

A list of all test materials is provided in Additional file 1 the Supporting Information. All non-powder samples, including cottonseed, rapeseed, corn liquor dregs, and nontransgenic potatoes, were ground into a 60 -mesh powder. The genomic DNA was extracted and purified using the Nucleic Acid Extraction System np968 (Tianlong Science and Technology Co., Ltd, Xi'an, China) in accordance with the manufacturer's instructions. This DNA extraction method involves four successive steps: (1) each ground sample $(50 \mathrm{mg}$ ) was added to $300 \mu \mathrm{L}$ DNA extraction buffer; (2) the samples were homogenized and incubated with lysis buffer; (3) the samples were centrifuged, and the supernatant collected; and (4) the nucleic acids were extracted using magnetic beads.

The relative sensitivity of the samples was determined according to the procedure below. A series of different percentages $100 \%, 10 \%, 1 \%, 0.1 \%, 0.01 \%$, and $0.001 \%(\mathrm{v} / \mathrm{v})$ of the transgenic potato preps were made individually after mixing transgenic potato DNA-containing supernatant with non-transgenic potato DNA-containing supernatant. The $100 \%$ transgenic potato preps were obtained after mixing $1000 \mu \mathrm{L}$ of transgenic potato DNA-containing supernatant with $0 \mu \mathrm{L}$ of non-transgenic potato DNA-containing supernatant, and $10 \%$ transgenic potato preps were was obtained after mixing $100 \mu \mathrm{L}$ of transgenic potato DNA-containing supernatant with $900 \mu \mathrm{L}$ of non- 
transgenic potato DNA-containing supernatant, etc. The transgenic potatoes were converted into nontransgenic potatoes at $100 \%, 10 \%, 1 \%, 0.1 \%, 0.01 \%$, and $0.001 \%(\mathrm{v} / \mathrm{v})$. The quantity of DNA samples was measured at $260 \mathrm{~nm}$ and prepared into solutions of $10 \mathrm{ng} / \mu \mathrm{L}$ for real-time PCR and ddPCR. The DNA purity was evaluated based on A260/A280 ratios using a UV spectrophotometer (BioPhotometer plus, Eppendorf, Germany).

\section{Determination of the 5 '-flanking DNA sequence}

The 5 '-flanking DNA sequence of transgenic potato AV436-G7 was determined using the $5^{\prime}$-RACE method. Based on the partial sequence of the lac gene in heterologous DNA in potato AV43-6-G7 [19], the 5' ends were obtained through the rapid amplification of cDNA ends (RACE) using gene-specific and adapter primers. For 5'-RACE, PCR was performed using the gene-specific outer primer MAV43 R1 and primer AP1. The DNA sample was amplified a $25-\mu \mathrm{L}$ reaction in a $0.2-\mathrm{mL}$ tube containing $200 \mathrm{nM}$ of primer gene-specific outer primer MAV43 R1 and primer AP1, 2× GC Buffer (TaKaRa DRR02AG, China), $2 \mathrm{mM}$ magnesium chloride, $200 \mathrm{nM}$ each of dATP, dCTP, dGTP, and dTTP, 1 unit of LA Taq (TaKaRa DRR02AG, China) and $100 \mathrm{ng}$ of the extracted DNA template. The PCR program was set at $95^{\circ} \mathrm{C}$ for $5 \mathrm{~min}$, followed by 10 cycles at $94{ }^{\circ} \mathrm{C}$ for $30 \mathrm{~s}, 68{ }^{\circ} \mathrm{C}$ (less than $0.8{ }^{\circ} \mathrm{C}$ per cycle) for $30 \mathrm{~s}$, and $72{ }^{\circ} \mathrm{C}$ for $150 \mathrm{~s}$ and $30-$ cycles at $94{ }^{\circ} \mathrm{C}$ for $30 \mathrm{~s}, 60{ }^{\circ} \mathrm{C}$ for $30 \mathrm{~s}$ and $72{ }^{\circ} \mathrm{C}$ for $150 \mathrm{~s}$, with a final cycle at $72{ }^{\circ} \mathrm{C}$ for another $10 \mathrm{~min}$.

Nested PCR was performed using the gene-specific outer primer MAV43 R2 and primer AP2. The DNA sample was amplified in a $25-\mu \mathrm{L}$ reaction in a $0.2-\mathrm{mL}$ tube containing $200 \mathrm{nM}$ of each primer MAV43 R1 and primer AP1, 2× GC Buffer (TaKaRa DRR02AG, China), 2 mM magnesium chloride, $200 \mathrm{nM}$ each of dATP, dCTP, dGTP and dTTP, 1 unit of LA Taq (TaKaRa DRR02AG, China), and100 ng extracted DNA template. The PCR was conducted at $95{ }^{\circ} \mathrm{C}$ for $5 \mathrm{~min}$, followed by 28 cycles at $94{ }^{\circ} \mathrm{C}$ for $30 \mathrm{~s}, 58{ }^{\circ} \mathrm{C}$ for $30 \mathrm{~s}$, and $72{ }^{\circ} \mathrm{C}$ for $150 \mathrm{~s}$, with a final cycle at $72{ }^{\circ} \mathrm{C}$ for another $10 \mathrm{~min}$.

\section{Oligonucleotide primers and probe}

The oligonucleotide primers and probe used in this study were designed using Primer Express version 3.0 (Applied Biosystems) and are listed in Table 1. For potato, the betafructosidase gene (fru) was selected as an endogenous reference gene [20]. The locations of the designed eventspecific primer pairs and probes targeting the DNA sequence are shown in Fig. 1. All primers and probes were synthesized at Sangon Co. Ltd. (Shanghai, China).

\section{Qualitative PCR assays}

The potato endogenous beta-fructosidase gene (fru) and event-specific sequence of GM potato AV43-6-G7 were separately amplified using potato AV43-6-G7 DNA and 24 negative non potato AV43-6-G7 DNA samples.

Real-time PCR was performed with a real-time PCR instrument (Master Cycle Realplex4, Eppendorf, Germany). Each DNA sample was amplified in a $25-\mu \mathrm{L}$ reaction in a 0.2-mL tube containing $200 \mathrm{nM}$ each of primer F, primer $\mathrm{R}$, and probe, 10× Taq Buffer (Transgene, Beijing, China), $2 \mathrm{mM}$ magnesium chloride, $200 \mathrm{nM}$ each of dATP, dCTP, dGTP and dTTP, 1.5 units of Taq DNA polymerase (Transgen, Beijing, China), and 100 ng of extracted DNA template [21]. After initial denaturation at $95{ }^{\circ} \mathrm{C}$ for $120 \mathrm{~s}$, the PCR conditions were optimized through 45 cycles of amplification (at $95{ }^{\circ} \mathrm{C}$ for $15 \mathrm{~s}$, and $60{ }^{\circ} \mathrm{C}$ for $30 \mathrm{~s}$ ). In each RT-PCR setup, the reaction systems were filled with purified water (non template control, NTC) and negative sample DNA as negative controls. The same baseline was used for the threshold cycle $(\mathrm{Ct})$ to compare the RT-PCR performances of the extracted DNA and negative DNA samples. For sensitivity tests of event-specific primers and probes, the concentration of the DNA template ranged from 0.001 to $100 \mathrm{ng}$.

\section{Droplet digital PCR reactions and analysis}

Droplet digital PCR was performed using a Bio-Rad QX100 droplet system (Bio-Rad, Pleasanton, CA, USA). The reaction mixtures contained $10 \mu \mathrm{L}$ of $2 \times$ ddPCR $^{\text {ts }}$ Supermix (Bio-Rad, Pleasanton, CA, USA) for probe, $1 \mu \mathrm{L}$ of primer and probe, and $5 \mu \mathrm{L}$ of DNA template, in a total reaction volume of $20 \mu \mathrm{L}$. Each concentration was repeated in three parallel reaction cells. The optimized cycling program for ddPCR assays included a denaturation step at $95{ }^{\circ} \mathrm{C}$ for $10 \mathrm{~min}$, followed by 45 cycles at $94{ }^{\circ} \mathrm{C}$ for $30 \mathrm{~s}, 60{ }^{\circ} \mathrm{C}$ for $1 \mathrm{~min}$, and $98^{\circ} \mathrm{C}$ for $10 \mathrm{~min}$. After PCR cycling, the fluorescence signals were collected using a QX100 droplet reader. The data were acquired and analysed using Quanta Soft software [22].

The absolute sensitivity of the samples was realized after diluting $100 \%$ genomic DNA to a $10 \mathrm{ng} / \mu \mathrm{l}$ solution. Subsequently, the $10 \mathrm{ng} / \mu \mathrm{l}$ solution was diluted 5 times at a 10-fold dilution.

Duplex droplet digital PCR reactions were performed using a FAM-labelled probe for the endogenous gene fru and a VIC-labelled probe for the AV43-6-G7-specific sequence at a concentration of $1 \times 10^{-5} \mathrm{ng} / \mu \mathrm{L}$ [23], with 10 repeat reactions.

The detection data for ddPCR using Bio-Rad platforms was analysed using Bio-Rad analysis software (Bio-Rad). The number of positive partitions for both event-specific and endogenous amplifications for each sample were counted using Bio-Rad platforms. Based on the Poisson distribution, the original copy number of the different samples was calculated using the following equations [24]: 
Table 1 Primers and probe in this study

\begin{tabular}{lll}
\hline Name & Sequence and labled fluorescence $\left(5^{\prime}-\right.$-3') $^{\prime}$ & Origin \\
\hline potato endogenous gene fru $-\mathrm{F}$ & CTGCCTCCGTCAAGATTGGTCACT & [12] \\
potato endogenous gene fru-R & CTCTTCCCTTCTTGATGG & [12] \\
potato endogenous gene fru-P & FAM-ACTTGTAATTCATCAAGCCAT- BHQ1 & [12] \\
MAV43 R1 & GCAAGCTTGGCGTAATCATGGTCATA & this study \\
MAV43-R 2 & CGCTCACAATTCCACACAACATACGA & this study \\
AP1 primer & GTAATACGACTCACTATAGGGC & this study \\
AP 2 primer & ACTATAGGGCACGCGTGGT & this study \\
Potato AV43-6-G7 primerF & GGTATCAGGTTCTGGAATAAGACCAA & this study \\
Potato AV43-6-G7 primerR & TGTCGTGCCAGCTGCATTA & this study \\
Potato AV43-6-G7 Probe & FAM-CCCGCGCGTTGGCCGAT-BHQ1 & this study \\
Potato AV43-6-G7 Probe used in duplex ddPCR & VIC-CCCGCGCGTTGGCCGAT-BHQ1 & this study \\
\hline
\end{tabular}

$\mathrm{A}(\mathrm{AV} 43-6-\mathrm{G} 7$ specific sequence $)=-\ln [(\mathrm{N}-\mathrm{X}) / \mathrm{N}] \times \mathrm{N}$

$\mathrm{B}($ endogenous gene fru $)=-\ln [(\mathrm{N}-\mathrm{Y}) / \mathrm{N}] \times \mathrm{N}$

In the above two equations, A (AV43-6-G7 specific sequence) and $B$ (endogenous gene fru) were the estimated copy numbers of the endogenous and eventspecific genes for each panel. $\mathrm{N}$ was the total number of partitions; and $\mathrm{X}$ and $\mathrm{Y}$ were the positive wells for the AV43-6-G7 event-specific genes and the endogenous

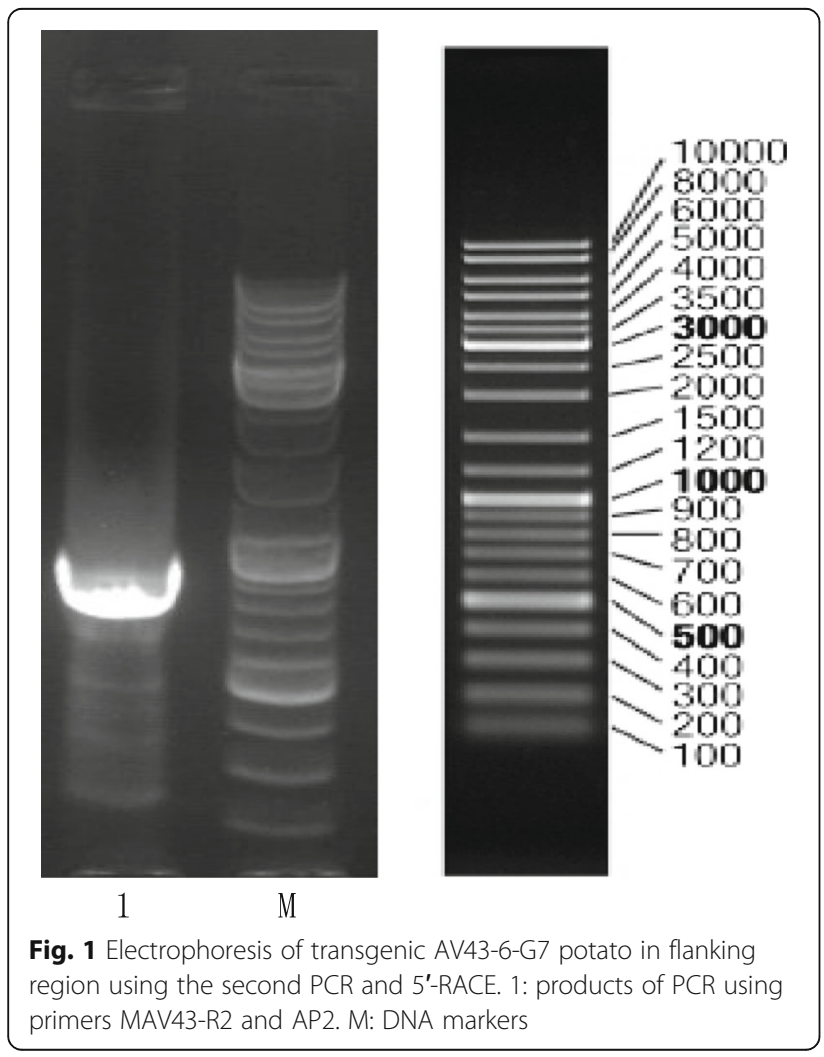

gene fru. The GMO proportion was calculated using the following equation:

$$
\frac{\mathrm{A}(\mathrm{AV} 43-6-\mathrm{G} 7 \text { specific sequence })}{\mathrm{B}(\text { endogenous gene } \mathrm{fru})} \times 0.62
$$

In equation (3), 0.62 was used as a correction coefficient for the different copy numbers of endogenous gene and screening gene in the genome. Ten samples of pure GM potato AV43-6-G7 were utilized to examine the AV43-6G7 event-specific sequence and the endogenous gene fru using digital PCR. The average ratio of AV43-6-G7 eventspecific sequence and endogenous gene fru was 0.62 .

\section{Results}

Characterization of the 5'-flanking region of transgenic AV43-6-G7 potato

According to information of "Overall Application of Amylopectin Potato Event AV43-6-G7 Based on Regulation (EC) on 1829/2003" from the website (http://www.gmocompass.org/pdf/regulation/potato/AV43-6-G7_applicat ion_food_feed_cultivation.pdf) [25], the integrated heterologous DNA in potato AV43-6-G7 is shown in Fig. 1. The DNA fragment (shown in Fig. 1) was derived from the 5 '-flanking region using 5 '-RACE.

To identify and analyse the junction region of the exogenous integrant and the host genomic DNA of potatoes, 4 specific primers (MAV43 R1, MAV43-R 2, AP1, and AP2) were designed based on the sequence of the Lac operon from M13 mp 19 to amplify the $5^{\prime}$-flanking sequences using $5^{\prime}$-RACE. The RACE-PCR product was sequenced. Figure 2 shows the $5^{\prime}$-junction sequence of an exogenous integrant of the AV43-6-G7 potato. This sequence comprised a 239-bp fragment from M13 mp 19 and an unknown 221-bp DNA sequence.

Because there is little sequence-related information on the potato genome available from the GenBank database, it was impossible to determine whether the unknown DNA 


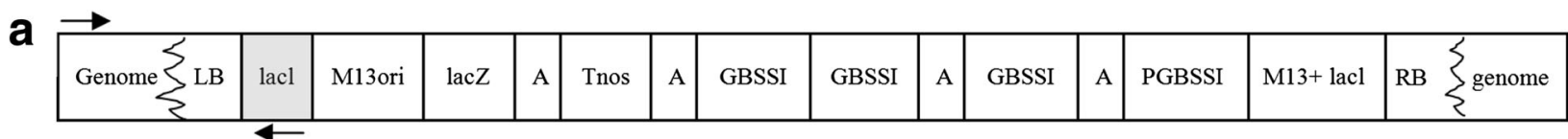

b

1 TTCAGGCCGC AGCTTCTGTG GTTCAGGTTG TGGTTCAGGC CGCGGCTCAGG TTGCGGCTCA AGCCTCTACT ACCGTCGCA

81 GATCAAGATG CAGCTACTGT GGTTCAGGTT GTGGTTCAGG CCGCGGCTCCG GTTGCGGCTC AAGCCTCTAC TACCGTCGC primerF

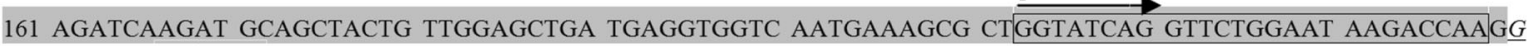
probe

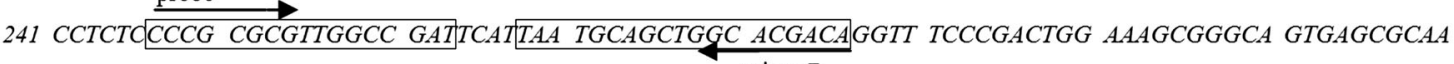
primerR

321 CGCAATTAAT GTGAGTTAGC TCACTCATTA GGCACCCCAG GCTTTACACT TTATGCTTCC GGCTCGTATG TTGTGTGGAA

401 TTGTGAGCGg ATAACAATtT CACACAGgAa ACAGCTATGA CCATGATTAC GCCAAGCTTG

Fig. 2 Frame of transgenic elements in the AV43-6-G7 potato genome. a Schematic diagram of the integrated exogenous gene in AV43-6-G7 potato, where ' $A$ ' means artificial poly linker sequence; $\mathbf{b}$ Flanking sequence of the potato genome and left border sequence of exogenous gene. The sequence in the grey background was obtained from the potato genome, while the other sequence was exogenous and obtained from the left border and the lacl gene. The sequence of primer $\mathrm{F}$ was obtained from the potato genome, and that of primer $\mathrm{R}$ and probe was obtained from the AV43-6-G7 potato

sequence $(221 \mathrm{bp})$ was derived from the potato genome. Therefore, 1 pair of specific primers (Table 1) was designed based on the 470-bp DNA sequence, and qualitative PCR was performed using the DNA of AV43-6-G7 potato, GMO PH05-026-0048 potato, wild potato, and 24 other GMO plant lines as templates. As expected, specific DNA amplification was observed in AV43-6-G7 potato, GMO PH05026-0048 potato, and wild potato, but unobservable in the other 24 GMO plant lines (Fig. 3). Hence, the unknown DNA sequence was derived from the potato genome.

\section{Specific for AV43-6-G7 potato of real-time PCR assay}

Based on the revealed 5 '-flanking sequence, event-specific primers were designed and used in a qualitative PCR assay of AV43-6-G7 potato. As expected, following the eventspecific qualitative PCR assay of AV43-6-G7 potato, a passive real-time PCR amplification curve was obtained for AV43-6-G7 potato, whereas no amplification curve was observed for the other GM lines [26] (Fig. 3).

The amplification curves and standard curve were obtained for GM AV43-6-G7 potato using real-time
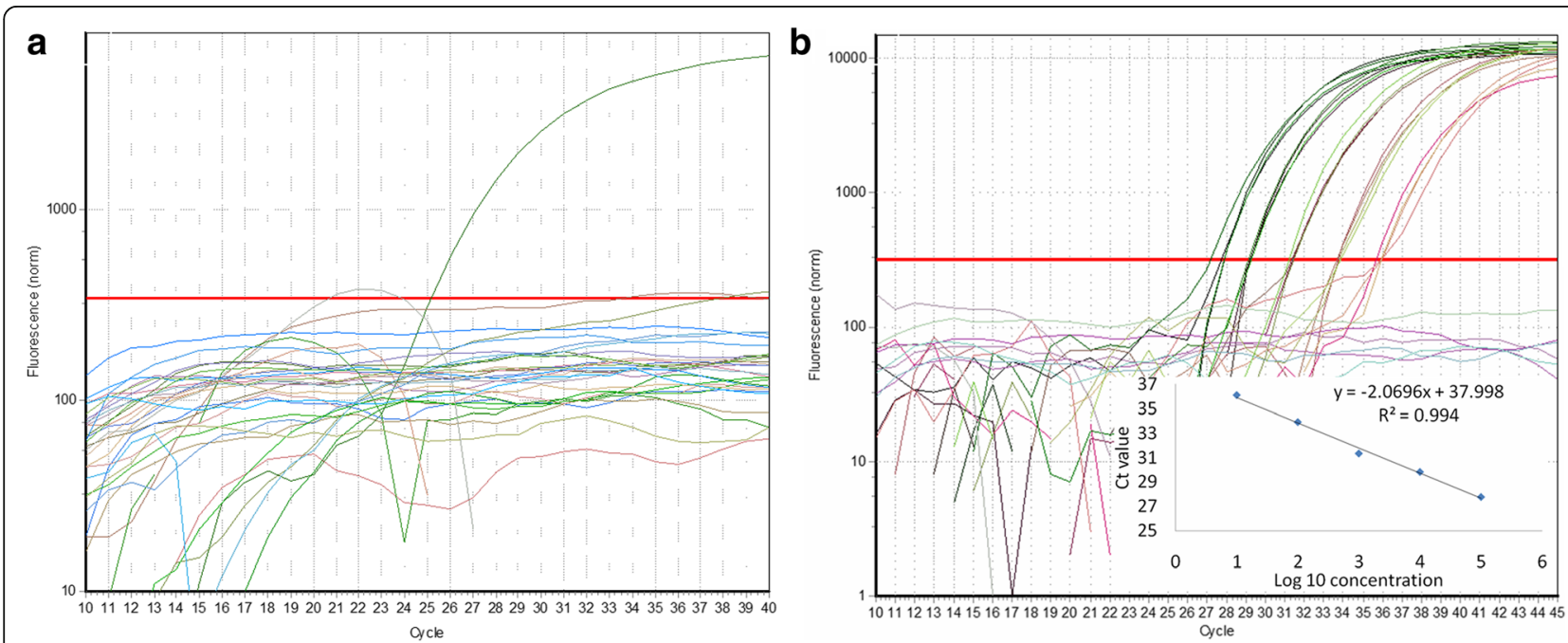

Fig. 3 The amplification curves and standard curve for detecting GM AV43-6-G7 potato using real-time PCR. a Specificity Tests of AV43-6-G7 Potato and the Other 24 Plant Samples. b Amplification Plots and Standard Curve for the Event-specific Quantitative PCR Assay of AV43-6-G7 Potato. Amplification curves (the amount of the serially diluted genomic DNA of AV43-6-G7 potato was 100, 10, 1, 0.1, 0.01 , and 0.001 ng AV43-6-G7 potato in a total of 100 ng DNA, respectively corresponding to $100 \%, 10 \%, 1 \%, 0.1 \%, 0.01 \%$, and $0.001 \%$ of AV43-6-G7 potato haploid genome in a total of $100 \mathrm{ng}$ of DNA per reaction) were generated to quantify AV43-6-G7 potato 
PCR. (A) Specificity Tests of AV43-6-G7 Potato and Other 24 Plant Samples. (B) Amplification Plots and Standard Curve for the Event-specific Quantitative PCR Assay of AV43-6-G7 Potato. Amplification curves (the amount of the serially diluted genomic AV43-6-G7 potato DNA was 100, 10, 1, 0.1, 0.01, and 0.001 ng AV43-6-G7 potato DNA in a total $100 \mathrm{ng}$ of DNA, respectively corresponding to $100 \%, 10 \%, 1 \%, 0.1 \%, 0.01 \%$, and $0.001 \%$ of the AV43-6-G7 potato haploid genome in a total of 100 ng DNA per reaction) were generated to quantify AV43-6-G7 potato.

\section{Determination of the LOD of real-time PCR}

To test the limit of detection (LOD) of the established method of event-specific real-time PCR, the DNA templates diluted along seven gradients were prepared at concentrations of $100 \%, 10 \%, 1 \%, 0.1 \%, 0.01 \%$, and $0.001 \%$, corresponding to $100,10,1,0.1,0.01$, and $0.001 \mathrm{ng}$ AV43-6-G7 potato haploid genome in a total of $100 \mathrm{ng}$ of DNA per reaction, respectively. A total of 4 parallel reactions were performed among triplicate samples. As expected, AV43-6-G7 potato DNA at $0.01 \mathrm{ng}$, corresponding to approximately $0.01 \% \mathrm{ng}$ of genomic DNA of AV43-6-G7 potato, was detected. The quantitative PCR results showed that the squared regression coefficient (R2) of the standard curve was 0.994 (Fig. 3). The high PCR efficiency and favourable linear relationship between the log DNA quantity and the fluorescence value $(\mathrm{Ct})$ suggested that these primers and probes were suitable for quantitative measurements of AV43-6-G7 potato genomic DNA. Hence, the LOD of the eventspecific quantitative PCR assay was $0.01 \mathrm{ng} /$ action genomic DNA.

\section{Determining the LOQ of ddPCR}

Given the limitations of ddPCR for the quantification of GMO in food and feed samples, particularly at low target levels and in some complex matrices, generally accepted minimum performance requirements for analytical methods should be satisfied [27]. To avoid biases in comparing real-time PCR with ddPCR, inter-laboratory validation of real-time qPCR assays were alternatively used to validate the ddPCR using minimum adaptation. Therefore, apart from the master mix and settings specific to the QX100 droplet system, the primers and probe nucleotide sequences and concentrations, DNA concentration, and PCR thermo-profile were the same as those used in the real-time PCR assays (Fig. 4).

The absolute limit of quantification (LOQ) is the lowest target copy number in a sample that can be reliably quantified with an acceptable level of precision and accuracy [28]. In the absolute sensitivity analysis, all samples for determining dynamic range were prepared through serial dilution of a single stock AV43-6-G7 potato-specific DNA sample. The genomic DNA of AV43-6-G7 potato was tested along 5 concentration gradients. For each sample, copies of the endogene and flanking sequence were separately measured using ddPCR. For individual endogene
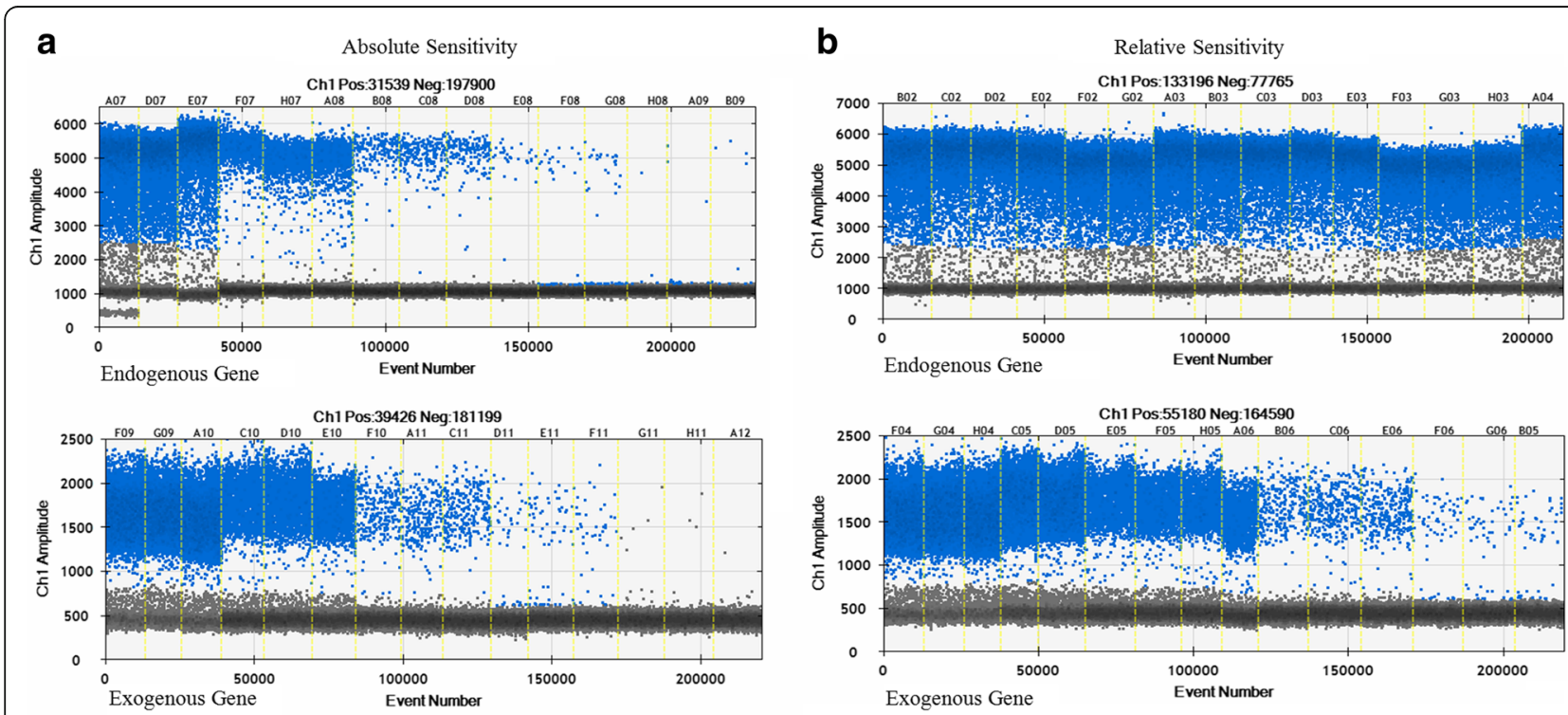

Fig. 4 The digital PCR picture of serial concentration of genomic DNA in AV43-6-G7 potato in absolute sensitivity and relative sensitivity analysis. a Analysis of Absolute Sensitivity. DNA was diluted along five concentration gradients, including 10, 1, 0.1, 0.01, and 0.001 ng/ $\mu \mathrm{L}$, from left to right. For each concentration, three parallel samples were tested. b Analysis of Relative Sensitivity. Samples with a concentration of $100 \%, 50 \%, 10 \%$, $1 \%$, and $0.1 \%$ of AV43-6-G7 potato haploid genome per reaction concentration are shown from left to right, respectively. Three parallel samples were tested for each concentration 
Table 2 Relative sensitivity for the AV43-6-G7 potato

\begin{tabular}{|c|c|c|c|c|c|}
\hline Prepared concentration & $\begin{array}{l}\text { AV43-6-G7 potato } \\
\text { genome DNA }\end{array}$ & Total template DNA & $\begin{array}{l}\text { Copies of AV43-6-G7 } \\
\text { potato genome }\end{array}$ & $\begin{array}{l}\text { Group average } \\
\text { concentration }\end{array}$ & Group RSD \\
\hline $100 \%$ & $50 \mathrm{ng} /$ reaction & $50 \mathrm{ng} /$ reaction & 57948.5 & $100.2 \%$ & $0.5 \%$ \\
\hline $50 \%$ & $25 \mathrm{ng} /$ reaction & $50 \mathrm{ng} /$ reaction & 28974.5 & $53.4 \%$ & $0.2 \%$ \\
\hline $10 \%$ & $5 \mathrm{ng} /$ reaction & $50 \mathrm{ng} /$ reaction & 5795.0 & $10.6 \%$ & $2.8 \%$ \\
\hline $1 \%$ & $0.5 \mathrm{ng} /$ reaction & $50 \mathrm{ng} /$ reaction & 579.5 & $1.1 \%$ & $4.0 \%$ \\
\hline $0.1 \%$ & $0.05 \mathrm{ng} /$ reaction & $50 \mathrm{ng} /$ reaction & 58.0 & $0.12 \%$ & $8.2 \%$ \\
\hline
\end{tabular}

targets and for the flanking sequence content, the coefficient of correlation $\mathrm{R}^{2}$ was 0.9849 and 0.9842 , respectively (Additional file 2). The correlation coefficients obtained from ddPCR met the requirements $\left(R^{2} .0 .98\right)$ set by the European Union Reference Laboratory for GM Food and Feed for acceptance of a quantitative PCR-based detection method for GMO [28] (Table 2).

In analysing relative sensitivity, the DNA template was diluted at a concentration of $100 \%, 50 \%, 10 \%, 1 \%$, and $0.1 \%$ of AV43-6-G7 potato haploid genome, respectively. When $0.1 \%$ sample of AV43-6-G7 potato in a total of $50 \mathrm{ng} /$ reaction potato DNA was detected, the experimental values and group RSD (relative standard deviation) were high, thus the accuracy of sample concentrations was higher than $0.1 \%$ AV43-6-G7 potato in a total $50 \mathrm{ng} /$ reaction potato DNA. The LOQ of each target group in the ddPCR assays was estimated as the lowest copy number within the dynamic with a relative standard deviation (RSD) of the measured copy number $\leq 25 \%$ [28]. When the nucleic acid concentration is $50 \mathrm{ng}$ per reaction, the $0.1 \%$ concentration of the target nucleic acid can be quantified as $0.12 \%$, with an RSD of $8.2 \%$. The results in duplex droplet digital PCR reactions with $0.1 \%$ target nucleic acid were quantified as $0.09 \%$, with an RSD of $9.7 \%$ [13, 29] (Fig. 5).

This result was consistent with the requirements of the test methods [28]. Because the genome size of the potato is $840 \mathrm{Mb}$ [30], the LOQ for ddPCR was 58 copies in a total of $50 \mathrm{ng} \mathrm{DNA} /$ reaction, consistent with a range from 30 to 100 copies in routine qPCR testing [22] (Table 3).

\section{Discussion}

This finding demonstrates that the AV43-6-G7 potato/ hmg ddPCR assay can be performed over a wide range of target concentrations to determine the AV43-6-G7 potato content in a given sample and that values of approximately 11.6 copies constitute the range of quantification with ddPCR. The absolute limit of quantification (aLOQ) is the lowest target copy number in a sample that can be reliably quantified with acceptable precision and accuracy [31]. The aLOQ of ddPCR systems for hmg or AV43-6-G7 potato was estimated as the lowest copy number of 1.2 (Table 2), which was within the dynamic range with a

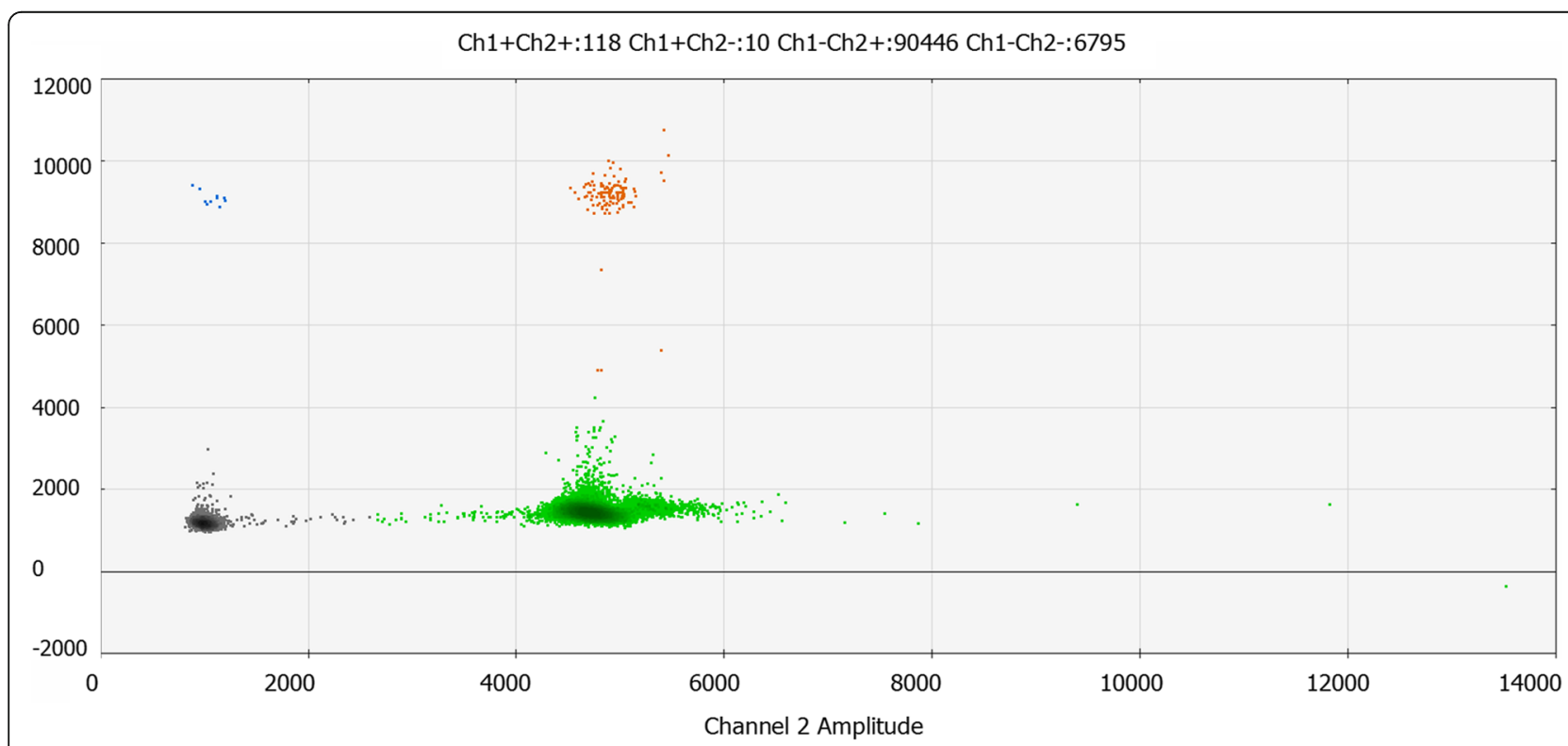

Fig. 5 The amplification hot maps of ddPCR using the Bio-Rad system. For the different colours in C, black indicates negative for both FAM and $\mathrm{VIC}$, the blue and green indicate positive only for FAM or VIC, and orange indicates positive for both FAM and VIC 
Table 3 Absolute sensitivity for AV43-6-G7 potato

\begin{tabular}{llll}
\hline $\begin{array}{l}\text { DNA concentration } \\
\text { of target }\end{array}$ & $\begin{array}{l}\text { Copies of AV43-6-G7 } \\
\text { potato genome }\end{array}$ & Group average & Group RSD \\
\hline $10 \mathrm{ng} /$ reaction & 11589.5 & $103.32 \%$ & $5.8 \%$ \\
$1 \mathrm{ng} /$ reaction & 1159.0 & $107.31 \%$ & $3.5 \%$ \\
$0.1 \mathrm{ng} /$ reaction & 115.9 & $93.39 \%$ & $8.7 \%$ \\
$0.01 \mathrm{ng} /$ reaction & 11.6 & $97.29 \%$ & $17.6 \%$ \\
$0.001 \mathrm{ng} /$ reaction & 1.2 & $95.14 \%$ & $24.9 \%$ \\
\hline
\end{tabular}

coefficient of variation (CV) of the measured copy number of $25 \%$ [28]. Based on this criterion, aLOQ was estimated at approximately 1.2 copies for the system. The results showed that ddPCR and real-time PCR have their own advantages. The applicability of ddPCR for GMO detection has previously been investigated and demonstrated as comparable to real-time PCR [32].

\section{Conclusions}

In the present study, the 5 '-exogene integration sequence was isolated, and event-specific qualitative and quantitative PCR assays were performed for identifying and quantifying Potato AV43-6-G7. The LOD of real-time PCR was 11.6 copies. A total of 58 copies, corresponding to a concentration of $0.1 \%$, reflected the relative sensitivity. In relative sensitivity experience, the lowest concentration was $0.1 \%$, which was considered practically sensitive, as this value was lower than the thresholds of $0.9 \%$ in EU. The ddPCR assays of Potato AV43-6-G7 introduced and performed here achieved a limit of quantification of approximately 58 target copies with an RSD $\leq 25 \%$. The aLOQ of this system was approximately 1.2 copies. These results suggested that these methods are suitable for detecting the GMO content in internationally traded products.

\section{Additional files}

Additional file 1: The names and sources of GM positive and negative samples used in the present study. (DOCX $14 \mathrm{~kb}$ )

Additional file 2: The copies of endogene and flanking sequence were separately measured using $\mathrm{ddPCR}$ in absolute sensitivity analysis. (XLSX $16 \mathrm{~kb}$ )

\section{Abbreviations}

aLOQ: absolute limit of quantification; CdPCR: chamber digital PCR; CV: coefficient of variation; ddPCR: droplet digital PCR; dPCR: digital PCR; GMO: genetically modified organisms; LOD: limit of detection; LOQ: limit of quantification; NTC: non-template control; qPCR: quantitative PCR; $\mathrm{R}^{2}$ : coefficient of correlation; RACE: rapid-amplification of CDNA ends; RSD: relative standard deviation

\section{Acknowledgements}

Not applicable.

\section{Funding}

This work was financially supported through grants from the Quality inspection public welfare research Project (201410014) and the National
Grand Project of Science and Technology (2016ZX08012-001). The funders had no role in study design, data collection and analysis, decision to publish, or preparation of the manuscript.

\section{Availability of data and materials}

All other materials produced as part of this study will be made available upon request.

\section{Authors' contributions}

HG performed the 5'-RACE, designed the primers and probe for real-time $P C R$, and drafted the manuscript. $X Y, M S$, and $X X$ performed the real-time PCR experiments. TD and YC performed the ddPCR experiments. $\mathrm{XH}$ and $\mathrm{HL}$ conceived the study, participated in the study design and coordination, and assisted with drafting the manuscript. All authors read and approved the final manuscript

\section{Competing interests}

The authors declare that they have no competing interests.

\section{Consent for publication}

Not applicable.

Ethics approval and consent to participate

Not applicable.

\section{Author details}

${ }^{1}$ Shandong Entry-Exit Inspection and Quarantine Bureau of People's Republic of China, Qingdao, China. ${ }^{2}$ Qingdao University Medical College, Qingdao, China. ${ }^{3}$ Chinese Academy of Inspection and Quarantine Institute, Beijing,

China.

Received: 6 May 2016 Accepted: 13 October 2016

Published online: 27 October 2016

\section{References}

1. Redenbaugh K, Hiatt B, Martineau B, Kramer M, Sheehy R, Sanders R, Houck C, Emlay D. Safety Assessment of Genetically Engineered Fruits and VegeTables: ACase Study of the Flavr Savr Tomato. Boca Raton: CRC Press; 1992. p. 288.

2. The International Service for the Acquisition of Agri-Biotech, pplications ISAAA. http://www.isaaa.org/gmapproval-database/eventslist/default.asp. Accessed 5 Apr 2016.

3. Meyerson LA, Reaser JK. Biosecurity: moving toward a comprehensive approach. BioScience. 2002;52(7):593-600.

4. Broeders S, Keersmaecker S, Roosens N. How to deal with the upcoming challenges in GMO detection in food and feed. Biomed Res Int. 2012;Article ID 402418:11. http://dx.doi.org/10.1155/2012/402418.

5. Zhao J, Sheng JP. Problem and confusion about GMO food labeling. J China Agricultural University. 2015;20(3):1-8. Chinese.

6. Yeku O, Frohman MA. Rapid amplification of cDNA ends (RACE). Methods Mol Biol. 2011;703:107-22. doi:10.1007/978-1-59745-248-98.

7. Liu YG, Chen YL. High-efficiency thermal asymmetric interlaced PCR for amplification of unknown flanking sequences. Biotechniques. 2007;43(5):649-56

8. Fraiturea MA, Hermanb P, Taverniersc I, Loosec MD, Deforced D, Roosensa $\mathrm{NH}$. An innovative and integrated approach based on DNA walking to identify unauthorised GMOs. Food Chem. 2014;147(15):60-9.

9. Krüger N-J, Buhler C, Iwobi AN, Huber I, Ellerbroek L, Appel B, et al. "Limits of control" - crucial parameters for a reliable quantification of viable campylobacter by real-time PCR. PLoS One. 2014;9(2):e88108. doi:10.1371/ journal.pone.0088108.

10. Baker M. Digital PCR, hits its stride. Nat Methods. 2012;9(6):541-4.

11. Burns M, Mburrell A, Afoy C. The applicability of digital PCR for the assessment of detection limits in GMO analysis. Eur Food Res Technol. 2010;231(3):353-62.

12. Stevanato $P$, Biscarini F. Digital PCR as new approach to SNP genotyping in sugar beet. Sugar Tech. 2015. doi:10.1007/s12355-015-0408-8.

13. Zhu PY, Fu W, Wang CG, Du ZX, Huang KL, Zhu SF, Xu WT. Development and application of absolute quantitative detection by duplex chamberbased digital PCR of genetically modified maize events without pretreatment steps. Anal Chim Acta. 2016;916(15):60-6.

14. Dany M, Dejan S, Mojca M, Kristina G, Jana Z, et al. Quantitative analysis of food and feed samples with droplet digital PCR. PLoS One. 2013;8(5):e62583. 
15. Jhansi RS, Usha R. Transgenic plants: Types, benefits, public concerns and future. J Pharm Res. 2013;6(8):879-83.

16. Atoevs E, Fguenthner J, Jjohnson A, Smcintosh C, Kthornton M. An industry perspective of all-native and transgenic potatoes. AgBioForum. 2011;14(1):14-9.

17. Ryffel GU. Making the most of GM potatoes. Nat Biotechnol. 2010;28:318.

18. BASF Plant Science Company GmbH. Application EFSA-GMO-MS-2010-XX Application for authorizations of Amylopectin potato AM04-1020 for food and feed uses, processing and cultivation according to regulation (EC) No 1829/2003.

19. Sonnewald U, Kossmann J. Starches-from current models to genetic engineering. Plant Biotechnol J. 2013;11:223-32.

20. Chaouachi M, El Malki R, Berard A, Romaniuk M, Laval V, Brunel D, Bertheau Y. Development of a real-time PCR method for the differential detection and quantification of four solanaceae in GMO analysis: potato (solanum tuberosum), tomato (solanum lycopersicum), eggplant (solanum melongena), and pepper (capsicum annuum). J Agric Food Chem. 2008;56(6):1818-28.

21. Li P, Jia JW, Jiang LX, Zhu H, Bai L, Wang JB, Tang XM, Pan AH. Eventspecific qualitative and quantitative PCR detection of the GMO carnation (Dianthus caryophyllus variety Moonlite based upon the 5'-exogene integration sequence. Genet Mol Res. 2012;11(2):1117-29.

22. David D, Bjørn S, Alexandra BK, Arne HJ, Jana Ž. Multiplex quantification of 12 European union authorized genetically modified maize lines with droplet digital polymerase chain reaction. Anal Chem. 2015;87:8218-26.

23. Huggett JF, Foy CA, Benes V, Emslie K, Garson JA, Haynes R, Hellemans J, Kubista M, Mueller RD, Nolan T, Pfaffl MW, Shipley GL, Vandesompele J, Wittwer CT, Bustin SA. Guidelines for minimum information for publication of quantitative digital PCR experiments. Clin Chim. 2013;59(6):1-12.

24. Zhu PY, Wang CG, Huang KL, Luo YB, Xu WT. A novel pretreatment-free duplex chamber digital PCR detection system for the absolute quantitation of GMO samples. Int J Mol Sci. 2016;17(3):402. doi:10.3390/ijms17030402.

25. GMO compass. Summary Application for amylopectin potato event AV43-6-G7 according to Regulation(EC) on 1829/2003. AVEBE: GM Partll Summary. http:// www.gmo-compass.org/pdf/regulation/potato/AV43-6-G7_application_food_ feed_cultivation.pdf. Accessed 15 Jun 2015.

26. Li X, Wang XX, Yang J, Liu YM, He YP, Pan LW. A novel quadruplex real-time PCR method for simultaneous detection of CryzAe and two genetically modified cotton events (GHB119 and T304-40). BMC Biotechnol. 2014;14:43.

27. Morisset D, Štebih D, Milavec M, Gruden K, Žel J. Quantitative analysis of food and feed samples with droplet digital PCR. PLoS One. 2013;8(5): e62583. doi:10.1371/journal.pone.0062583.

28. EURL-GMFF.Definition of Minimun Performance Requirements for Analytical Methods of GMO Testing European Network of GMO Laboratories (ENGL), http://gmo-crl.jrc.ec.europa.eu/doc/Min_Perf_Requirements_Analytical_ methods.pdf. Accessed 22 Jan 2016.

29. Cheng N, Zhu PY, Xu YC, Huang KL, Luo YB, Yang ZS, Xu WT. Highsensitivity assay for $\mathrm{Hg}$ (II) and $\mathrm{Ag}$ (I) ion detection: a new class of droplet digital PCR logic gates for an intelligent DNA calculator. Biosens Bioelectron. 2016;84(15):1-6.

30. Arumuganathan K, Earle ED. Nuclear DNA content of some important plant species. Plant Mol Biol Reporter. 1991;9:210-20

31. Moon GS, Shin WS. Establishment of quantitative analysis method for genetically modified maize using a reference plasmid and novel primers. Prev Nutr Food Sci. 2012;17:74-279.

32. Milavec M, Dobnik D, Yang LT, Zhang DB, Gruden K, Žel J. GMO quantification: valuable experience and insights for the future. Anal Bioanal Chem. 2014;406(26):6485-97.

\section{Submit your next manuscript to BioMed Central and we will help you at every step:}

- We accept pre-submission inquiries

- Our selector tool helps you to find the most relevant journal

- We provide round the clock customer support

- Convenient online submission

- Thorough peer review

- Inclusion in PubMed and all major indexing services

- Maximum visibility for your research

Submit your manuscript at www.biomedcentral.com/submit
C Biomed Central 